\title{
Effect of Galohgor Cookies Intake by Postpartum Mother on Newborn's Growth
}

\author{
Ibnu Malkan Bakhrul IImi ${ }^{1,2}$, Rimbawan ${ }^{1 *}$, Katrin Roosita ${ }^{1}$, Zakiudin Munasir $^{3}$
}

\begin{abstract}
Background: Health and nutritional problems are commonly found in postpartum mothers. Prevention of vitamin A deficiency including in postpartum mothers continues to be done. Utilization of local food such as Galohgor might be an alternative to address the nutritional needs of postpartum mothers and thus supports newborn's growth.

Objectives: This study aimed to analyze the effect of Galohgor cookies intake by postpartum mothers on newborn's growth. Methods: This research used a quasi-experimental design with two groups including the control group $(n=9)$ and the intervention group $(n=9)$. The subjects were postpartum mothers aged 20-35 years (parity between 2 and 5 ) with normal delivery and had no medical indication. A total of four pieces of cookie ( $4 \mathrm{~g}$ of Galohgor powder) were daily consumed from the $1^{\text {st }}$ day to the 40 days after delivery. Anthropometric measurements (body weight, height, head circumference) were performed on day 0, 14 and 40 after delivery. Meanwhile, breast milk samples were taken on day 14 and 40 to analyze the levels of breast milk insulin-like growth factor-1 (IGF-1).

Results: This study showed that the newborns of the intervention group had significantly heavier weight and larger head circumference on day 14 and 40 after delivery $(p<0.05)$. IGF-1 could be maintained by consuming Galohgor during postpartum period. However, this study found no differences in body length of both groups ( $p>0.05)$.

Conclusions: Consumption of Galohgor cookies by postpartum mothers might support the newborn's growth.

Keywords: Galohgor, growth, IGF-1, newborn, postpartum mother
\end{abstract}

\author{
*Correspondence: \\ Rimbawan \\ Email : (rimbawan62@yahoo.com) \\ 1Departemen Gizi Masyarakat, Fakultas Ekologi Manusia, IPB University, Bogor, Indonesia \\ ¿Program Studi IImu Gizi, Fakultas IImu Kesehatan, Universitas Pembangunan Nasional "Veteran”, Jakarta, Indonesia \\ 'Departemen Ilmu Kesehatan Anak, Fakultas Kedokteran, Universitas Indonesia, Jakarta, Indonesia
}

\section{INTRODUCTION}

Early development is a critical period that determining the future nutritional status ${ }^{1}$. Pospartum is an important period lasted for 6 weeks after delivery when the mother and baby adapt to the new environment ${ }^{2}$. Several health problems have been reported during postpartum, including anemia, depression, harmful beliefs and practices, oxidative stress and vitamin A deficiency ${ }^{3-7}$. Free radicals increase after delivery and lead to oxidative stress $^{8}$. Elevated tumor necrosis factor- $\alpha$ (TNF- $\alpha$ ) level was observed during the gestation and continued to increase at postpartum ${ }^{6}$. This may affect newborn's growth due to the negative association between TNF- $\alpha$ and growth hormones and the quality of milk ${ }^{8,9}$. Meanwhile, vitamin $A$ has been widely known as an antioxidant that effectively neutralizes free radicals ${ }^{10}$.

Vitamin A is one of nutrient that is important for growth $^{11}$. Besides being conventionally functioning for vision, vitamin A plays an important role in regulating growth hormones, boosting the immune system, and regulating the expression of several genes related to growth $^{12,13}$. To meet vitamin A requirement, several countries give a high-dose vitamin A tablets $(200,000 \mathrm{IU})$ to postpartum mothers. This program contributes to reduce the prevalence of vitamin A deficiency (retinol levels $<20 \mu \mathrm{g} / \mathrm{dl}$ ) among under-five children in Indonesia to be less than $5 \%^{14}$. However, this program is costly, does not change an individual's eating behavior and is still at risk of deficiency in the event of stress, diarrhea, measles or other diseases ${ }^{15}$. Furthermore, the recent study showed that $44 \%$ of breastfeeding mothers in Indonesia did not meet the estimated average requirement (EAR) of vitamin $A^{7}$.

Galohgor is a native Sundanese herbal medicine made from 56 types of plants, including leaves, stems, fruits, nuts, herbs and spices, commonly consumed by postpartum mothers and rich in vitamin $A$ and $\beta$ carotene ${ }^{16-18}$. Galohgor has been shown to accelerate uterine recovery and lactation time, and to increase milk production in experimental animals ${ }^{16}$. Genetically, $\beta$ carotene is believed to be responsible for galactogogic effect of Galohgor by enhancing the expression of the connexin ( $\mathrm{Cx} 43$ ) and $\beta$-casein (Csn2) genes ${ }^{17}$. In addition, Galohgor has also been shown to improve blood glucose, visceral fat profiles and to reduce oxidative stress ${ }^{19,20}$. Hence, Galohgor might give health benefits to the postpartum mothers.

However, the acceptance of Galohgor is relatively low due to unpleasant taste, especially for those who are not accustomed. Fortunately, Galohgor has been developed into various products. Galohgor cookie is one of the developed products that commercially sold and has 
been tested on patients with type 2 diabetes mellitus. The result showed Galohgor cookies reduced visceral fat, reduced malondialdehyde, and maintained liver and kidney function ${ }^{16,18,21}$. Our recent study showed that Galohgor cookies reduced oxidative stress in postpartum mothers ${ }^{22}$. However, its effect on early development had not been studied yet. Therefore, this study aimed to examine the effect of Galohgor cookies intake by postpartum mothers on newborn's growth.

\section{METHOD}

\section{Materials}

Galohgor cookies were obtained from CV. Nutraseutikal Galohgor, Bogor (P-IRT No. 2063201010485-22). The cookies contained $1 \mathrm{~g}$ of Galohgor, while the control cookies did not contain Galohgor. The main ingredients of cookie were wheat flour, egg yolk, milk, sugar, margarine, salt, and coconut milk. A total of $50 \mathrm{ml}$ of breast milk was taken using breast pump electric spectra S1 plus to analyze IGF-1 concentrations. The breast milk was kept under $-80^{\circ} \mathrm{C}$ for analysis. The baby scale Seca 232 was used to measure both weight and length of the newborns, while nonstretchable tape were used to measure head circumference.

\section{Subjects}

The subjects were screened in several Community Health Centers (CHFs) in Bogor, including CHF of Pancasan, Cipaku, Kayumanis, Sempur and Warung Jambu. The subjects were mothers aged 20-35 years old (parity between 2 and 5 ) and had a single pregnancy. Mothers were healthy and able to communicate. Postpartum mothers with premature infant $(<2500 \mathrm{~g})$ and/ or the labor performed by cesarean section were excluded. There were 18 subjects divided into 2 groups, the intervention group and the control group. This number was calculated using Lemeshow and colleagues ${ }^{23}$ formula with a confidence interval $(1-\alpha)$ of $90 \%$ and power of test $(1-\beta)$ of $80 \%$.

\section{Procedures of Intervention}

The present study used a quasi-experimental design. The mothers with gestational age between week 30 and 33 , and visited the community health centers for prenatal care were included for screening. The informed consent was provided and signed by all subjects. The eligible subjects were divided to receive either Galohgor cookies $(n=9)$ or control cookies $(n=9)$. A total of $40 \mathrm{~g}$ of cookies were daily given for 40 days (day 1 to day 40 after birth). At baseline, the age of mothers, parity, the birth length, weight, and head circumferences were assessed. The subjects were suggested to exclusively breastfeed their infants and to eat healthy diet. The breast milk was taken at day 14 and 40 . On day 14 after birth, the breast milk is relatively mature whereas the nutritional contents tend to be consistent for the next several months ${ }^{24}$. The second point of sampling was determined due to probably the end stage of puerperium ${ }^{25}$. To improve subject's compliance, the cookies were given once each 5 days, the subjects were monitored using short message service every day. All study protocols have been approved by the Research Ethics Committee of IPB University, Indonesia (No.081/IT3.KEPMSM-IPB/SK/2018).

\section{Anthropometric Assessment}

The newborns were measured according to the standard protocols ${ }^{26}$. The measurement of weight was done by removing all the child's clothes. The baby scale measured to the nearest $5 \mathrm{~g}$. Simultaneously, the length was measured by holding the newborn's legs, positioning the head and straightening them. The crown touched the headboard to make Frankfort plane positioned vertically. The shoulders and hips were positioned to the long axis of the body. The footboard was moved against the newborn's feet with the toe pointing upwards. There were two observers needed for the length measurement. The baby scale measured the length to the nearest $1 \mathrm{~mm}$. The non-stretchable tape was applied around the head. The tape position was above the eyebrows and covered the fullest protuberance of the skull. The measurement was recorded by tightening the tape to compress the hair and skin. The non-stretchable tape measured to the nearest $1 \mathrm{~mm}$.

\section{Breast milk IGF-1 Analysis}

The breast milk IGF was measured using the Human IGF-1 Quantikine enzyme linked immunosorbent assay (ELISA) kit (the quality of Human IGF-I quantikine ELISA kit is certified with ISO 13485: 2003 and EN ISO 13485: 2012). The samples were thawed before analysis. The fat of breast milk was separated using centrifugation at 30.000 for $15 \mathrm{~m}$. After removing the fat layer, a total of $40 \mu \mathrm{l}$ of sample was pipetted into the test tubes containing buffer solution. The test tubes were then added $80 \mu \mathrm{l}$ of antibody. The samples in the tubes were subsequently assigned to the well plate. The plate was sealed and incubated at room temperature for $30 \mathrm{~m}$. After incubation, the plates were washed using buffer solution. The stopping solution was pipetted and the plate was read at $450 \mathrm{~nm}^{27}$.

\section{Data Analysis}

Data were presented in mean \pm standard deviation (SD). The differences between groups was tested using independent t-test, while the differences between day 14 and 40 of intervention was tested using paired t-test. P-value $<0.05$ was considered to be significant.

\section{RESULTS AND DISCUSSION}

The characteristics of subjects and their newborns were equally distributed at baseline assessment (Table 1). The subjects were around 30 years and were multiparous mothers with parity between 2 and 3. Both groups had the average newborn's birth weight, length, and head circumference more than $3 \mathrm{~kg}, 48 \mathrm{~cm}$, $32 \mathrm{~cm}$ respectively. All anthropometric measurements showed positive changes between the measurement at day 14 and day 40 for both groups. The weight of newborns differed significantly at day 14 and day 40 between the control and intervention groups. The same 
pattern did also appear in head circumference. However, the length did not differ at those points. The newborns in intervention group seemed to have heavier weight and larger head than the control group (Table 2). The result of breast milk analysis showed that IGF-1 concentrations were found to be significantly different between the control and intervention groups only at day 40 . IGF concentration significantly decreased in the control group, whereas it could be maintained in the intervention group during postpartum (Table 3 ).

Table 1. Characteristics of Subjects at Baseline

\begin{tabular}{lll}
\hline Characteristics & $\begin{array}{l}\text { Control }(\mathbf{n}=\mathbf{9}) \\
\text { Mean } \pm \text { SD }\end{array}$ & $\begin{array}{l}\text { Intervention }(\mathbf{n}=\mathbf{9}) \\
\text { Mean } \pm \text { SD }\end{array}$ \\
\hline Age (year) & $30.33 \pm 4.000$ & $31.22 \pm 5.286$ \\
Parity & $2.56 \pm 0.726$ & $2.78 \pm 0.667$ \\
Birth weight $(\mathrm{kg})$ & $3.017 \pm 0.292$ & $3.311 \pm 0.322$ \\
Birth length $(\mathrm{cm})$ & $48.667 \pm 1.870$ & $50.111 \pm 1.900$ \\
Birth circumference $(\mathrm{cm})$ & $32.277 \pm 0.971$ & $33.333 \pm 1.391$ \\
\hline
\end{tabular}

Galohgor has long been used by postpartum mothers in the Sundanese community ${ }^{16}$. Several studies have scientifically proven the benefits of galohgor for postpartum mothers ${ }^{16,17}$. This study supports those scientific evidences whereas Galohgor cookies appeared to be able to support the growth of newborns. Even though the body length differences were not statistically significant, the value was relatively higher in the intervention group than the control group. This was thought to be caused by body length is a function of longterm health and nutritional experiences ${ }^{28}$. Supporting growth effect of Galohgor was believed due to increased levels of breast milk IGF-1 which absorbed intact by infants in early life ${ }^{24}$.

Oxidative stress often occurs especially after delivery. Noor et al. ${ }^{29}$ showed TNF- $\alpha$ increased in postpartum caused by increased oxygen consumption and the apnea during uterine contractions. Unfortunately, TNF- $\alpha$ concentration is negatively associated with IGF-1 production ${ }^{9,30-32}$. According to Lang et al. ${ }^{32}$ TNF- $\alpha$ might interfere with signal transduction and synthesis of growth hormone (GH) receptors thus giving rise to resistance. Growth hormone resistance causes the inhibition of IGF-1 synthesis. Also, the inhibition of GH receptors inhibits the capacity of cells to bind to GH. TNF$\alpha$ inhibits sp1 and sp3 bond which are transcription factors for growth hormone genes. In addition, TNF- $\alpha$ also enhances the expression of SOSC-3 and CIS which play an antagonistic effect to the growth hormone signaling pathways ${ }^{33}$.

Table 2. Weight, Length and Head Circumference of Newborns at Day 14 and 40

\begin{tabular}{lll}
\hline Parameters & $\begin{array}{l}\text { Control }(\mathbf{n}=\mathbf{9}) \\
\text { Mean } \pm \text { SD }\end{array}$ & $\begin{array}{l}\text { Intervention }(\mathbf{n}=\mathbf{9}) \\
\text { Mean } \pm \text { SD }\end{array}$ \\
\hline Weight $(\mathrm{kg})$ & $3.198 \pm 0.311$ & $3.680 \pm 0.335$ \\
Day $14^{*}$ & $4.095 \pm 0.426$ & $4.648 \pm 0.350$ \\
Day $40^{*}$ & $+0.896 \pm 0.243^{* *}$ & $+0.968 \pm 0.185^{* *}$ \\
Changes & & \\
Length $(\mathrm{cm})$ & $51.144 \pm 1.664$ & $52.322 \pm 1.980$ \\
Day 14 & $53.633 \pm 1.335$ & $54.277 \pm 1.801$ \\
Day 40 & $+2.488 \pm 2.406^{* *}$ & $+1.955 \pm 1.558^{* *}$ \\
Changes & & \\
Head Circumference $(\mathrm{cm})$ & $33.811 \pm 1.550$ & $35.655 \pm 1.377$ \\
Day 14* & $38.422 \pm 0.359$ & $39,611 \pm 1.176$ \\
Day 40* & $+4.611 \pm 1.446^{* *}$ & $+3.955 \pm 0.918^{* *}$ \\
Changes &
\end{tabular}

$*$ The difference between groups is significant at the 0.05 level

** The difference between day 14 and 40 in the group is significant at the 0.05 level

Galohgor is a potential source of antioxidants ${ }^{18,19}$. This biological activity reduces oxidative stress and increases IGF-1 expression. It can be seen from the other parts of this study that reported by Ma'rifah et al. ${ }^{22}$ and showed that Galohgor cookies reduced malondialdehyde levels in postpartum mothers. The high $\beta$-carotene content in Galohgor was thought to underlie the mechanism. The supplementation of $\beta$-carotene has been reported to reduce oxidative stress, elevate glutathione level in lead-exposed workers ${ }^{34}$. The same results were found by Lee et al. ${ }^{35}$ who found protein oxidation and DNA damage decreased after administration of $\beta$-carotene of $9 \mathrm{mg}$ for four weeks in the active smokers. This finding is supported by observational research which showed that there was a negative correlation between $\beta$-carotene intake and oxidized lowdensity lipoprotein (ox-LDL) ${ }^{36}$. In addition, retinoic acid participates in development of the nervous system. Retinoic acid has two main roles including in the patterning and differentiation of neurons. In terms of patterning, retinoic acid contributes to the patterning of neural plates and neural tubes. Disruption of retinoic acid 
signaling causes imperfect development of hindbrain and anterior spinal cord. Induction of nerve cell differentiation by retinoic acid may occur due to the activation of several genes throughout affecting transcription factors, signaling molecules, structural proteins, enzymes and receptors ${ }^{37}$.

Table 3. IGF-1 Concentrations in Breast milk at Day 14 and 40 after Delivery

\begin{tabular}{lll}
\hline Parameters & $\begin{array}{l}\text { Control }(\mathbf{n}=\mathbf{9}) \\
\text { Mean } \pm \text { SD }\end{array}$ & $\begin{array}{l}\text { Intervention }(\mathbf{n}=\mathbf{9}) \\
\text { Mean } \pm \text { SD }\end{array}$ \\
\hline Day 14 & $0.416 \pm 0.097$ & $0.353 \pm 0.014$ \\
Day 40* & $0.321 \pm 0.028$ & $0.360 \pm 0.043$ \\
Changes & $-0.095 \pm 0.112^{* *}$ & $+0.018 \pm 0.056$ \\
\hline
\end{tabular}

$*$ The difference between groups is significant at the 0.05 level

** The difference between day 14 and 40 in the group is significant at the 0.05 level

$\beta$-carotene is a pro-vitamin A which plays an important role to meet vitamin $A$ requirement of pregnant and postpartum women ${ }^{38}$. An active vitamin $A$, retinoic acid, plays an important role in switch on the transcription of several genes ${ }^{39}$. A low vitamin A diet is associated with low IGF-1 gene expression. This research was conducted by $\mathrm{Fu}$ et al. ${ }^{40}$ by providing a vitamin $\mathrm{A}$ deficient diet to quails aged one day. A vitamin A deficient diet reduced $22 \%$ of serum IGF levels, $21-52 \%$ of IGF-1 mRNAs in the testes, lungs, liver, and heart and caused growth retardation.

Human IGF-1 is positively associated with baby's growth. Kon et al. ${ }^{41}$ found that there was a significant relationship between breast milk IGF-1 levels and the weight gain for 3-month-old infants. IGF-1 triggers proliferation, migration and inhibiting cell apoptosis ${ }^{42}$. The mechanism of action of IGF-1 is similar to the mechanism of insulin. IGF-1 binds to its receptors on the membrane and then induces autophosphorylation in a number of cell proteins including the insulin receptor substrate (IRSs) group. IRS is a docking protein that can activate a number of signaling pathways, such as phosphatidyl inositol 3-kinase (PI3K), Akt, Ras / Raf, and Rac. PI3K and Akt activation protect cells from potential loss of mitochondrial membrane and cytochrome c. This action inhibits caspase-3 activation which inhibits apoptosis.

There are several strengths of the present study, including relatively long period of intervention and high level of compliance. In addition, the clinical trial regarding the effect of foods on breast milk IGF-1 concentrations and newborn's growth at postpartum is still limited. However, the present study did not control food intake of subjects, thus daily intake of postpartum mothers may affect the results. Therefore, the future study needs to control food intake of postpartum mothers and investigate IGF-1 levels in baby to confirm whether newborn's growth is affected by IGF-1 status.

\section{CONCLUSION}

Galohgor cookies intake by postpartum mothers could support newborn's growth. Newborns of postpartum mothers who consumed Galohgor cookies had heavier weight and larger head circumferences. Galohgor cookies were also able to maintain breast milk IGF-1 concentration during postpartum period.

\section{ACKNOWLEDGEMENT}

We wish to thank to Indonesia Endowment Fund for Education, Ministry of Finance of Republic of Indonesia and the Ministry of Research, Technology and Higher Education for kindly financial support to this research.

\section{REFERENCE}

1. Black, R. E. et al. Maternal and child undernutrition and overweight in low-income and middle-income countries. Lancet 382, 427451 (2013).

2. WHO. WHO technical consultation on postpartum and postnatal care. World Heal. Organ. 1-56 (2010).

3. Milman, N. Postpartum anemia I: Definition, prevalence, causes, and consequences. Ann. Hematol. 90, 1247-1253 (2011).

4. Sein, K. K. Beliefs and practices surrounding postpartum period among Myanmar women. Midwifery 29, 1257-1263 (2013).

5. O'Hara, M. W. \& McCabe, J. E. Postpartum Depression: Current Status and Future Directions. Annu. Rev. Clin. Psychol. 9, 379-407 (2013).

6. Christian, L. M. \& Porter, K. Longitudinal changes in serum proinflammatory markers across pregnancy and postpartum: Effects of maternal body mass index. Cytokine 70, 134140 (2014).

7. Daniels, L. et al. Micronutrient intakes of lactating mothers and their association with breast milk concentrations and micronutrient adequacy of exclusively breastfed Indonesian infants. Am. J. Clin. Nutr. 110, 391-400 (2019).

8. Kuramoto, N. \& Kitagawa, M. Evaluation of Oxidative Stress, Antioxidant Power, and Antioxidant Potential of Breastmilk of BreastFeeding Mothers. Health (Irvine. Calif). 09, 1145-1158 (2017).

9. Zhao, Y., Xiao, X., Frank, S. J., Lin, H. Y. \& Xia, Y. Distinct mechanisms of induction of hepatic growth hormone resistance by endogenous IL-6, TNF- $\alpha$, and IL-1 $\beta$. Am. J. Physiol. - Endocrinol. Metab. 307, 186-198 (2014).

10. Palace, V. P., Khaper, N., Qin, Q. \& Singal, P. K. 
Antioxidant potentials of vitamin A and carotenoids and their relevance to heart disease. Free Radic. Biol. Med. 26, 746-761 (1999).

11. Imdad, A. et al. Impact of vitamin A supplementation on infant and childhood mortality. BMC Public Health 11, (2011).

12. Gil-Ibáñez, P., Bernal, J. \& Morte, B. Thyroid hormone regulation of gene expression in primary cerebrocortical cells: Role of thyroid hormone receptor subtypes and interactions with retinoic acid and glucocorticoids. PLoS One 9, (2014).

13. Erkelens, M. N. \& Mebius, R. E. Retinoic Acid and Immune Homeostasis: A Balancing Act. Trends Immunol. 38, 168-180 (2017).

14. Sandjaja, S. et al. Food consumption and nutritional and biochemical status of 0.5-12year-old Indonesian children: The SEANUTS study. Br. J. Nutr. 110, (2013).

15. Herman, S. Masalah Kurang Vitamin a (Kva) Dan Prospek Penanggulangannya. Media Heal. Res. Dev. 17, 40-44 (2012).

16. Damayati, R. P., Roosita, K. \& Sulaeman, A. Effect of Galohgor Cookies and Powder Drinks on Visceral Adipose Tissue and Lipid Profile in Patients with Type 2 Diabetes Mellitus. J. Gizi dan Pangan 13, 137-144 (2018).

17. Roosita, K., Rimbawan, R., Djuwita, I. \& Damanik, M. R. M. Peranan B -Karoten Dan Nutrasetikal Galohgor Dalam Proliferasi, Diferensiasi, Dan Ekspresi Gen Sel Epitel Usus (Cmt-93) Dan Sel Kelenjar Mammae (Hc11). Repos. IPB (2015).

18. Setyaningsih, S., Katrin, R. \& Damayanthi, E. Efek Produk Galohgor Terhadap Aktivitas Antioksidan dan Penurunan Stres Oksidatif Diabetes Melitus Tipe 2. Media Kesehat. Masy. Indones. 13, 310 (2017).

19. Leatemia, R. R., Marliyati, S. A. \& Setiawan, B. Antioxidant Activity of Galohgor Herbs in Rats (Rattus sp). Repos. IPB (2010).

20. Firdaus, F., Rimbawan, R., Marliyati, S. A. \& Roosita, K. Peran ekstrak nutrasetikal galohgor untuk mengatasi resistensi insulin pada tikus diabetes yang diinduksi streptozotocin (stz). Repos. IPB (2016).

21. Hasanah, L. N., Roosita, K. \& Rimbawan, R. Effect of Drinks and Cookies Contained Galohgor on Biomarker of Liver Function in Type 2 Diabetic Subjects. Ann. Nutr. Metab. 75, 1424 (2019).

22. Ma'rifah, B., Roosita, K. \& Sinaga, T. The Galohgor Nutraceutical Cookies Effects on ?Carotene Serum and Oxidative Stress of Postpartum Mothers. Prev. Nutr. Food Sci. 24, 381-386 (2019).

23. Lemeshow, S., Hosmer, D. W., Klar, J. \& Lwanga, S. K. Adequacy of Sample Size in Health Studies. Biometrics 47, 347 (1990).

24. Ballard, O. \& Morrow, A. L. Human Milk Composition. Nutrients and Bioactive Factors.
Pediatr. Clin. North Am. 60, 49-74 (2013).

25. Elsharkawy, S. Towel curettage for a new definition of postpartum period after cesarean section. Int. J. Reprod. Contraception, Obstet. Gynecol. 7, 2537 (2018).

26. Cheikh Ismail, L., Knight, H. E., Ohuma, E. O., Hoch, L. \& Chumlea, W. C. Anthropometric standardisation and quality control protocols for the construction of new, international, fetal and newborn growth standards: The INTERGROWTH-21st Project. BJOG An Int. J. Obstet. Gynaecol. 120, 48-55 (2013).

27. Gottfredson, L. M. Maternal Stress, Breastmilk IGF-1, and Offspring Growth among Breastfeeding Mothers-Infant Pairs in the Tampa Bay Area. 95 (2015).

28. WHO. Global Database on Child Growth and Malnutrition.

https://www.who.int/nutgrowthdb/about/intro duction/en/index2.html (2020).

29. Noor, N. et al. Normal delivery induced stress alters glutathione peroxidase and TNF- $\alpha$ in elderly primigravidas mononuclear cells. Indian J. Clin. Biochem. 23, 227-232 (2008).

30. Gude, M. F. et al. The production and regulation of IGF and IGFBPs in human adipose tissue cultures. Growth Horm. IGF Res. 22, 200-205 (2012).

31. Panjala, S. R., Jiang, Y., Kern, T. S., Thomas, S. A \& Steinle, J. J. Increased tumor necrosis factor$\alpha$, cleaved caspase 3 levels and insulin receptor substrate-1 phosphorylation in the $\beta$ 1adrenergic receptor knockout mouse. Mol. Vis. 17, 1822-1828 (2011).

32. Lang, C. H., Nystrom, G. J. \& Frost, R. A. Tissuespecific regulation of IGF-I and IGF-binding proteins in response to TNFa. Growth Horm. IGF Res. 11, 250-260 (2001).

33. Denson, L. A. et al. TNF- $\alpha$ downregulates murine hepatic growth hormone receptor expression by inhibiting Sp1 and Sp3 binding. J. Clin. Invest. 107, 1451-1458 (2001).

34. Kasperczyk, S. et al. Beta-carotene reduces oxidative stress, improves glutathione metabolism and modifies antioxidant defense systems in lead-exposed workers. Toxicol. Appl. Pharmacol. 280, 36-41 (2014).

35. Lee, B. M., Lee, S. K. \& Kim, H. S. Inhibition of oxidative DNA damage, 8-OHdG, and carbonyl contents in smokers treated with antioxidants (vitamin $\mathrm{E}$, vitamin $\mathrm{C}, \beta$-carotene and red ginseng). Cancer Lett. 132, 219-227 (1998).

36. Bacchetti, T., Turco, I., Urbano, A., Morresi, C. \& Ferretti, G. Relationship of fruit and vegetable intake to dietary antioxidant capacity and markers of oxidative stress: A sex-related study. Nutrition 61, 164-172 (2019).

37. Janesick, A., Wu, S. C. \& Blumberg, B. Retinoic acid signaling and neuronal differentiation. Cell. Mol. Life Sci. 72, 1559-1576 (2015).

38. Hotz, C. et al. Introduction of $\beta$-Carotene-Rich Orange Sweet Potato in Rural Uganda Resulted 
in Increased Vitamin A Intakes among Children and Women and Improved Vitamin A Status among Children. J. Nutr. 142, 1871-1880 (2012).

39. Zhang, R., Wang, Y., Li, R. \& Chen, G.

Transcriptional factors mediating retinoic acid signals in the control of energy metabolism. Int. J. Mol. Sci. 16, 14210-14244 (2015).

40. Fu, Z., Noguchi, T. \& Kato, H. Vitamin A Deficiency Reduces Insulin-Like Growth Factor (IGF)-I Gene Expression and Increases IGF-I Receptor and Insulin Receptor Gene Expression in Tissues of Japanese Quail (Coturnix coturnix japonica). J. Nutr. 131, 1189-1194 (2001).

41. Kon, I. Y., Shilina, N. M., Gmoshinskaya, M. V. \& Ivanushkina, T. A. The study of breast milk IGF1 , leptin, ghrelin and adiponectin levels as possible reasons of high weight gain in breastfed infants. Ann. Nutr. Metab. 65, 317-323 (2014).

42. Delafontaine, P., Song, Y. H. \& Li, Y. Expression, Regulation, and Function of IGF-1, IGF-1R, and IGF-1 Binding Proteins in Blood Vessels. Arterioscler. Thromb. Vasc. Biol. 24, 435-444 (2004). 